\title{
Idiopathic granulomatous mastitis: a case report of breast abscess
}

\author{
Molly L Olsen, Christina A Dilaveri \\ Department of Medicine, Mayo Clinic, Rochester, Minnesota, USA;
}

Correspondence to Dr Molly LOlsen, olsen.molly@mayo.edu

\begin{abstract}
Summary
Idiopathic granulomatous mastitis (IGM) is an uncommon breast disease often mistaken for breast infection or abscess. We present a case of IGM diagnosed after prolonged ineffective treatment of presumed infectious mastitis with abscess. Once the diagnosis was made with biopsy and further evaluation to exclude other causes of granulomatous disease, sinus tract debridement and closure by secondary intent resulted in resolution of symptoms in our patient. Many cases of IGM require immunosuppression with steroids, methotrexate or extensive surgery. To prevent morbidity, IGM should be considered in the differential diagnosis when presumed infectious mastitis with breast abscess does not respond to usual treatment.
\end{abstract}

\section{BACKGROUND}

This uncommon disease should be considered when usual therapy for breast infection or abscess does not improve symptoms. Only a high index of suspicion will prevent the morbidity of delayed diagnosis and misguided therapy.

\section{CASE PRESENTATION}

A 35-year-old white American woman presented with tenderness, warmth and redness in the upper inner quadrant of her right breast. The patient was concerned about her symptoms representing, infectious mastitis, which she had experienced during lactation 2 years prior. She denied fever, rash, synovitis, myalgias, lymphadenopathy or other systemic symptoms. Medical, surgical, family and social histories were unremarkable.

\section{INVESTIGATIONS}

She was initially diagnosed with presumed infectious mastitis and prescribed oral antibiotics. Over the next 2 months, her symptoms persisted despite antibiotic therapy. She repeatedly sought medical attention and each time, she was prescribed a new antibiotic course, totalling five separate courses. She completed each without improvement. Breast ultrasound was initially interpreted as negative for abscess. Repeat ultrasound showed small fluid collections, which were incised and drained without improvement. After 2 months of persistent symptoms despite incision and drainage and five courses of antibiotics, core needle biopsy was performed.

Pathology from core needle biopsies revealed suppurative granulomas. Stains as well as cultures for fungi and acid-fast bacilli were negative. Evaluation for autoimmune, connective tissue or infectious granulomatous disease was negative, including inflammatory markers, differential cell count, tuberculosis skin test, autoimmune and fungal serologic testing and chest imaging.

\section{DIFFERENTIAL DIAGNOSIS}

In available case reports and series, idiopathic granulomatous mastitis (IGM) often mimics two more common diseases, breast infection or abscess and breast cancer.

\section{TREATMENT}

A trial of systemic steroids was unsuccessful. She underwent further incision and drainage with sinus tract debridement and closure by secondary intention. Her symptoms completely resolved and as of 2 years later, have not recurred.

\section{DISCUSSION}

IGM, an uncommon benign breast disease that often masquerades as two other common conditions, breast abscess or carcinoma, was first described in $1972 .{ }^{1}$ To our knowledge, fewer than 100 cases are reported in the current literature. The condition is most common in women of child-bearing age $\mathrm{e}^{2}$ and is a diagnosis made by pathologic review after excluding infectious and autoimmune causes of granulomatous inflammation. Treatment depends on the severity of disease and may include observation, systemic steroids, methotrexate ${ }^{3}$ or surgery. ${ }^{1}$ Approximately half of all women have spontaneous resolution without specific therapy. ${ }^{4}$

\section{Learning points}

- IGM is often mistaken for breast abscess.

- This uncommon but not rare disease should be considered when usual therapy for breast abscess does not improve symptoms.

- Only a high index of suspicion will prevent the morbidity of delayed diagnosis and misguided therapy.

- Diagnosis is made on pathologic inspection followed by investigations to rule out other causes of granulomatous disease. 


\section{BMJ Case Reports}

Competing interests None.

Patient consent Obtained.

\section{REFERENCES}

1. Patel RA, Strickland P, Sankara IR, et al. Idiopathic granulomatous mastitis: case reports and review of literature. J Gen Intern Med 2010;25:270-3.
2. Bani-Hani KE, Yaghan RJ, Matalka II, et al. Idiopathic granulomatous mastitis: time to avoid unnecessary mastectomies. Breast $J$ 2004;10:318-22.

3. Schmajuk G, Genovese MC. First report of idiopathic granulomatous mastitis treated with methotrexate monotherapy. $J$ Rheumatol 2009;36:1559-60.

4. Lai EC, Chan WC, Ma TK, et al. The role of conservative treatment in idiopathic granulomatous mastitis. Breast J 2005;11:454-6.

This pdf has been created automatically from the final edited text and images.

Copyright 2011 BMJ Publishing Group. All rights reserved. For permission to reuse any of this content visit http://group.bmj.com/group/rights-licensing/permissions.

BMJ Case Report Fellows may re-use this article for personal use and teaching without any further permission.

Please cite this article as follows (you will need to access the article online to obtain the date of publication).

Olsen ML, Dilaveri CA. Idiopathic granulomatous mastitis: a case report of breast abscess. BMJ Case Reports 2011;10.1136/bcr.05.2011.4271, date of publication

Become a Fellow of BMJ Case Reports today and you can:

- Submit as many cases as you like

- Enjoy fast sympathetic peer review and rapid publication of accepted articles

- Access all the published articles

- Re-use any of the published material for personal use and teaching without further permission

For information on Institutional Fellowships contact consortiasales@bmjgroup.com

Visit casereports.bmj.com for more articles like this and to become a Fellow 